\author{
ANATOLIY KHUDOLIY \\ Ostroh Academy National University, Ukraine \\ toliy65@yahoo.com
}

\title{
A SEMANTIC-COGNITIVE ANALYSIS OF THE CONCEPT OF UKRAINE IN THE SPEECHES OF B. OBAMA (2014)
}

\begin{abstract}
This article presents a semantic-cognitive analysis of the concept of Ukraine, verbally represented in the speeches of the American President, Barak Obama. The peculiarities of the President's worldview are highlighted.

The objective of the article is as follows. Firstly, it aims to demonstrate that the concept of Ukraine is verbally represented in the speeches of Obama. This means that Ukraine as a country, moving towards democracy despite the war with Russia, is an object of focus for American leaders. Secondly, the article suggests that there is a connection between the concept described, its pragmatic orientation and its cognitive processes. Thirdly, it describes the semantic peculiarities of the concept of Ukraine in the political speeches of the American leader, which are due to the role Ukraine plays in the local and regional context.

Our research is based on the content-analysis of political speeches delivered by American President. The functional, communicative and pragmatic orientation of the speeches is highlighted. In line with the approaches of cognitive scholars, the article concludes that the concept of Ukraine is a complex semantic-cognitive structure that consists of core, transition zone and periphery. During the research for this article, fifteen speeches made by Obama in 2014 were analysed.

This research presupposes the application of content analysis. It is relevant in the analysis of international relations with respect to the notions used by President Obama in his speeches delivered during 2014 in the relations between: the USA - Ukraine, Ukraine - Russia, the USA - Russia, and Europe - Ukraine.
\end{abstract}

Keywords: political speech; concept; function; worldview; communication; cognition

\section{Introduction}

Within the development of communicative and cognitive paradigms, understanding and explaining statements made by American politicians is becoming more and more important, because the words and actions of American leaders are closely connected. This is why the mechanisms of idea perception, idea interpretation, and subsequent action are worth researching, not only from perspective of political scientists, but also from that of linguists. A cognitive approach is especially useful in the latter context.

In a broader perspective, the influence of politicians and their speeches is growing because they play an important role in the development of society and international relations. These factors 
reflect the attitude and behavior of American politicians. The study of political speeches (that reflect the worldview of the American political elite) and their influence on the consciousness of average people, their attitudes, as well as actions, is often neglected by researchers. This situation serves as a solid justification for linguistic research into this issue, especially, nowadays when political decisions affect the lives of people and countries.

\section{Theoretical Accounts of Concept Study}

The assessment of the political speeches of American leaders presupposes analyses of different aspects of political communication. These have been undertaken by Ukrainian, Russian, Polish and western scholars.

Regarding Ukrainian scholars, the political discourse of American presidents was studied by O. Fomenko (1998), who focused on the speeches delivered in the1990-s. I. Andrusiak (2008) analyzed the lexical units of political correctness, especially the nominative and pragmatic aspects. K. Serazhym (2002) summarized approaches to discourse studies and analyzed the social and linguistic peculiarities of this phenomenon. The pragmatic and functional characteristics of political discourse in the USA and Ukraine were studied by I. Butova (2011).

The efforts of Russian scholars to study the phenomenon of political speeches are represented by the following works: N. Mironova (1997) concentrated more on the evaluative character of political speeches. A. Chudinov (2007) dedicated his work to political linguistics, analyzing political speeches and taking into consideration a broad, communicative approach. Y. Sheigal (2002) studied the genre characteristics of political texts.

Polish studies are represented by the works of Anna Wierzbicka (1992), Elżbieta Górska (1993, 2010), Elżbieta Tabakowska (2004a, 2004b) and others.

Western research is represented by G. Lakoff (1980, 1996), G. Lakoff and M. Johnson (1999), John Joseph (2006), R. Hart, S. Jarvis, W. Jennings and D. Smith-Howell (2005), M. Krzywinsky (2015) and M. Kirkpatrick (2009). John Joseph (2006, pp. 1-17) studied the influence of politics on language and vice-versa His research deals mainly with semantics. Various aspects of language as a leadership instrument were studied by Roderick Hart, Sharon Jarvis, William Jennings and Deborah Smith-Howell (2005, p. 129). Martin Krzywinsky (2015) and Marshal Kirkpatrick (2009) conducted a lexical analysis of several speeches delivered by American presidents.

Much of the research mentioned above indicates substantial changes in the approaches to analyzing the linguistic peculiarities of American political speeches. Despite the broad range of issues studied by academia, the main concepts of American presidential speeches were beyond their scope. Therefore, the current study performs an analysis of the basic concepts represented in the speeches delivered by President Obama. Out of all the concepts identified as a result of this analysis, the leading one is the concept of Ukraine.

\section{The Analysis}

This article is based on the theoretical issues of communicative, cognitive and textual linguistics which concentrate on the characteristics and functions of texts of political communication. Political speeches, as indispensable components of political communication, are functionally oriented, i.e. they perform a set of functions in order to affect the audience. Communicative, cognitive, nominative, and pragmatic functions are just several of many others. These functions play an important role in the goals of the current research.

The political speeches of President Obama, delivered in 2014, serve as a source of illustrative material in the research. Every state leader is important, but the American president is unique. Statutorily, the president is the nation's chief diplomat, the manager of an enormous bureaucracy, the commander-in-chief of the military, and the head appointments officer. Culturally and politically, the president is a father-confessor, a role model, and the high priest in the nation's rituals. 
Without a monarchy, and with only a few hundred years of national history to depend on, the American people look to their president for political, financial, and emotional guidance, as well as for safety and protection (Hart et al., 2005, p. 129).

We interpret a political speech of an American president as a form of public discourse, a process of communication, and a kind of social action. Because a speech is implemented as action, delivered to many people, it is perceived as a socially oriented motivational action. Despite its formal character, a political speech also has a functional character and it is pragmatically oriented to affect the audience. It also conveys intentionally used cognitive and content-loaded structures.

Due to its communicative and social functions, language is not only a means of expression, but also a means of thought formation at a certain level of cognitive activity (Pavilionis, 1983, p. 16). So, from the cognitive point of view, the goal of a political speech is the construction of a specific model of situation or event depicted in the speech and, in addition to this, the renewal and detailing of more general models. A political speech is purposefully oriented to the formation of the goals, values and social-political strategy of one political group, and seeks to convey and impose information on electors and political opponents.

A communicative approach to the analysis of political speeches serves to study speech characteristics and factors of their representation in context. It reflects real connections between language units in communicative situations at the lexical and semantic levels (Levitskii, 1998, p. 9). The political speeches of American leaders are ideologically coloured. Speeches are delivered in order to cause changes in the audience's worldview and, over time, to push people to take action and change the political landscape. Symbolically, the idea can be illustrated in this way: political speeches $\rightarrow$ changes in communication $\rightarrow$ changes in worldview $\rightarrow$ changes in actions (Pocheptsov, 2000 , p. 97). It is well known that any social action is closely connected with language, which is a perfect means for the construction of content, conveying messages, and influencing action. Words and texts can, and do, convey political views in a hidden way so that the form, in some cases, can obscure the real meaning and thus serve as an important means of influence. Political speeches reflect the way politicians perceive the world and current affairs, and they reveal how they interpret them and want to change them. Such approaches have interesting cognitive features, as far as they are related to the rules, categories and procedures, applied by politicians in the process of depicting the situations described in speeches (van Deik, 1989, p. 233).

Political speech is goal-oriented. It is related to the governing and coordinating of human activity (Shveitser, 1976, p. 23). The influence of political speeches can be illustrated by the following component model: Entrance (E), Reinforcement (REI), Resonance (RES). The communicative chain looks like this: Entrance $\rightarrow$ Reinforcement $\rightarrow$ Resonance (Pocheptsov, 1999, p. 26). The component Entrance guarantees simultaneous and massive penetration into mass consciousness. Systematic Reinforcement, to be efficient, should correspond to the audience's demands. Information that is conveyed forms a communicative Resonance, which is more effective when it consists of apt verbal coinages that live independently after their application (Pocheptsov, 1999, p. 26). Political speeches reflect the ideological guiding lines of the political system. They are traditionally delivered in order to change the situation or to preserve the status quo (Altunian, 2006, p. 15).

Obama's political speeches are strategically oriented to preserve the balance of power in Eastern Europe, on the one hand, and to change the situation in Ukraine for better, on the other hand. Their basic functions are integration and differentiation. They are delivered to unite the American people and the international community in a confrontation with Russian aggression. At the same time, they are effective during the period of "the new cold war", a confrontation with the Russian Federation which, ignoring international laws, supports separatists in eastern Ukraine and poses a threat to Europe as a regional aggressor. In his speeches, Obama interprets the events in Ukraine, highlights the cause-and-effect connections, explains the correlations with other events and situations, draws conclusions, and assesses the events in the local and regional context. One more function of speeches is to control, so the American president makes efforts to lay the foundation for unification of thoughts, feelings and wants of both the American people, and the 
international audience.

Concepts are inseparable from political speeches; they reflect a politician's views, perception of events, and realia. They are complex mental formations that serve as standards for perception, political thought, and the formation and implementation of models of behaviour. They affect the political decisions of people, cause changes in human consciousness, and create images of countries and people. Concepts are intrinsically connected with the worldview of American politicians.

A conceptual worldview forms the basis of a linguistic worldview. The world a person lives in is reflected in the language used by this person. It is represented by grammatical structures and lexicon. Accepting the idea that lexicon is a model of the world, we cannot but accept the idea that any language fixes a certain amount of knowledge about its structure (world) and functioning. The results of people's cognitive activity are set in language, which is an implementation of thoughts and which is realized in communication with other people. This idea is represented below (Fig. 1) (Bondarenko, 2005, p. 59).

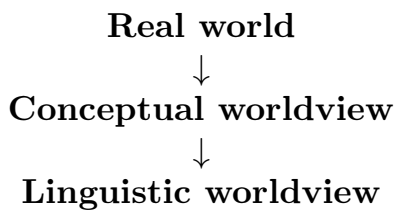

Figure 1: Correlation between reality and mental worldview

A linguistic worldview is a complex formation, which consists of mental units correlating with the political sphere of communication and political discourse. Logically, politicians in speeches reflect their typical models of behavior. Obama's speeches correspond to an existing model of mental and verbal conceptions about the world, and the place which the USA occupies in it.

In the current research, content-analysis was applied, which helps to identify a set of concepts represented in the speeches of President Obama. They are as follows: War, Peace, Enemy, Friend, Democracy, Cooperation, Threats, Leadership, Ukraine and Security etc. The dominant concept in 2014 was that of Ukraine. The identified concepts are not spontaneous; they appeared partly as a result of political traditions and stereotypes. The concept of Ukraine stands separate in the list, however, because over the last twelve months Ukraine has been a dominant topic of discussion in the spheres of politics and international relations.

Concepts are formed over time. Regarding a cognitive approach, it should be mentioned that concepts such as democracy, freedom, human rights, and democratic elections are basic ones, in so much as they are deeply rooted in the minds of the American people. At the same time, the conceptual sphere is sensitive to the slightest change in the lives of people, not to mention changes in the international arena. Concept formation and change depend on particular circumstances, events, people, and other factors. Therefore, when Russia annexed Crimea, thereby violating international law, it created a precedent for the formation of the image of aggression in the minds of American leaders.

Over the course of 2014, Ukraine attracted the American president's attention due to its democratic changes following the Maidan protests, and then due its status as a victim of Russian aggression. These events led to the formation of the concept of Ukraine.

The concept itself is a structure represented by sets of components (groups of words and word combinations) such as: Conflict in Ukraine (20 notions), Role of the USA (41 notions), Future of Ukraine (77 notions), Role of Europe (96 notions), Independence of Ukraine (250 notions) and Russian Illegal Actions (260 notions). The dominant components are: Independence of Ukraine, Future of Ukraine, Role of the USA, Role of Europe and Russian Illegal Actions. The structure of the concept of Ukraine presupposes the core, the transition zone and the periphery. The core includes the models consisting of the most useful notions, such as Russian Illegal Actions and Independence of Ukraine. The transition zone is represented by models such as Role of 
Europe, Future of Ukraine and Role of the USA. The periphery includes only one model, Conflict in Ukraine. The concept of Ukraine possesses certain characteristics that are important for it description and analysis.

Firstly, the concept is hierarchically structured. This means that the elements of the structure are closely connected. Additionally, the concept consists of models that are represented by groups of words and word combinations united under a general idea. Selected words and word combinations of the groups have syntagmatic and paradigmatic relationships.

Secondly, the borders between models in the concept are blurred. Analysing the components of the models brings one to the conclusion that they may belong to two or three models at the same time.

Thirdly, taking into consideration the peculiarities of the lexico-semantic fields, it can be confirmed that the concept Ukraine can be analyzed in terms of core, transition zone and periphery. Schematically, the analyzed concept can be represented as depicted below (see Fig. 2).

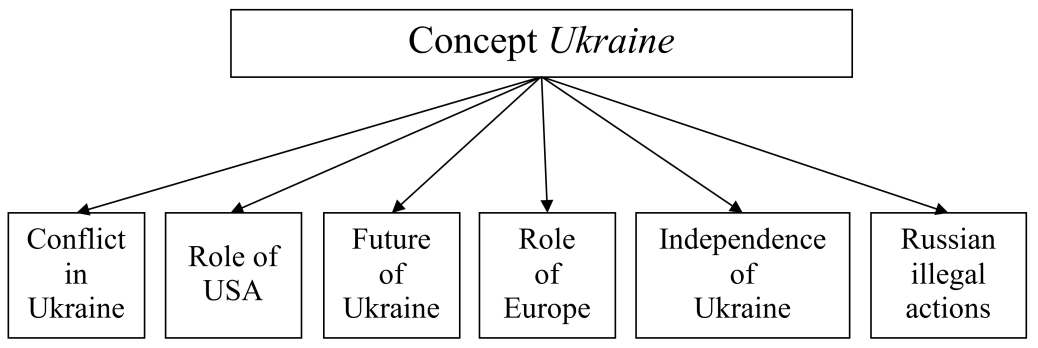

Figure 2: The concept of Ukraine identified in the speeches of B. Obama

The first model, which is located in the periphery, deals with Conflict in Ukraine. It is represented by the basic lexeme - conflict. The President usually employed the word conflict when talking about fighting in eastern Ukraine. It should be mentioned that the United States of America are actively participating in the events related to the conflict itself, and the improvement of Ukrainian-Russian relations. At the same time, the United States has made tremendous efforts to help both sides find a way out of the confrontation. The most efficient way to do this is Peaceful resolution, i.e. diplomatic solutions and negotiations (see Fig. 3 below). The core of the group consists of lexemes such as conflict in Ukraine and peaceful resolution. The rest of the lexemes serve as synonyms to the notion of resolution.

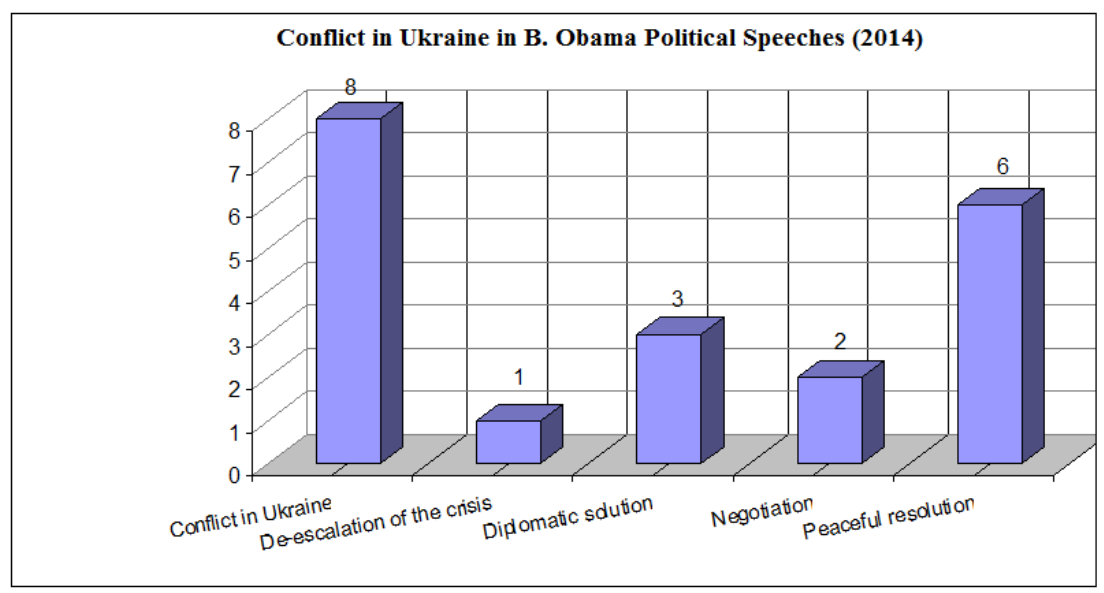

Figure 3: The conflict in Ukraine as represented in the speeches of B. Obama 
Altogether, the notions of the group comprise 20 units, which makes it the smallest group of all those identified in Obama's 2014 speeches. In terms of frequency, it belongs to the peripheral zone.

In the semantic-cognitive structure of the above-mentioned concept, the war in Ukraine poses a threat to peace and stability. The conflict in Ukraine has attracted Obama's attention because it acts as a source of aggression and instability, and represents a threat not only to Eastern Europe, but also for Central and Western Europe. For instance:

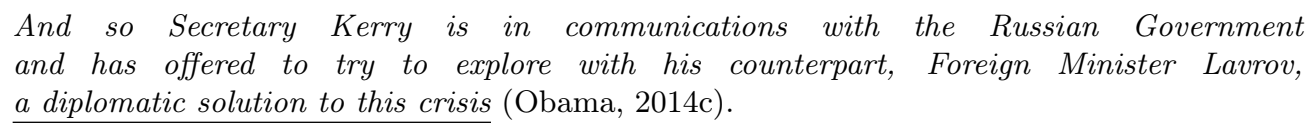

For President Obama it is quite obvious that the way out of the crisis is not a military confrontation, but a diplomatic solution. As a mediator, Washington has made efforts to help all parties - Ukraine, Russia and Europe - to save face and come to a peaceful resolution.

The most numerous notion in this group is that of conflict in Ukraine; less numerous are the notions of peaceful resolution, diplomatic solution, negotiation and de-escalation of the crisis. Contextually, the notion of negotiation is valid and well grounded, because it is the centerpiece of the conflict situation which demands resolution. For instance:

We call on Russia to address any ongoing security or human rights concerns that it has with Ukraine through direct negotiations, and/or via international observation or mediation under the auspices of the UN or the Organization for Security and Cooperation in Europe. We stand ready to assist with these efforts ("Joint Statement by Group of Seven Leaders on the situation in Ukraine", 2014a).

Despite the possibility of calling for a military solution of the conflict, Washington instead urges both sides to solve the problem peacefully through negotiations, which are, in Obama's opinion, the safest and most effective way of reaching a compromise. It should be mentioned that the lexeme negotiations is used only twice but, at the same time, President Obama uses synonymous words and word combinations such as diplomatic solution, peaceful resolution, de-escalation of the crisis etc.

The second model of the concept includes notions under the title Role of the USA (41 notions). They are dedicated to the role of the USA in the Russian-Ukrainian military conflict. This group of notions is more numerous than the previous one (see Fig. 4).

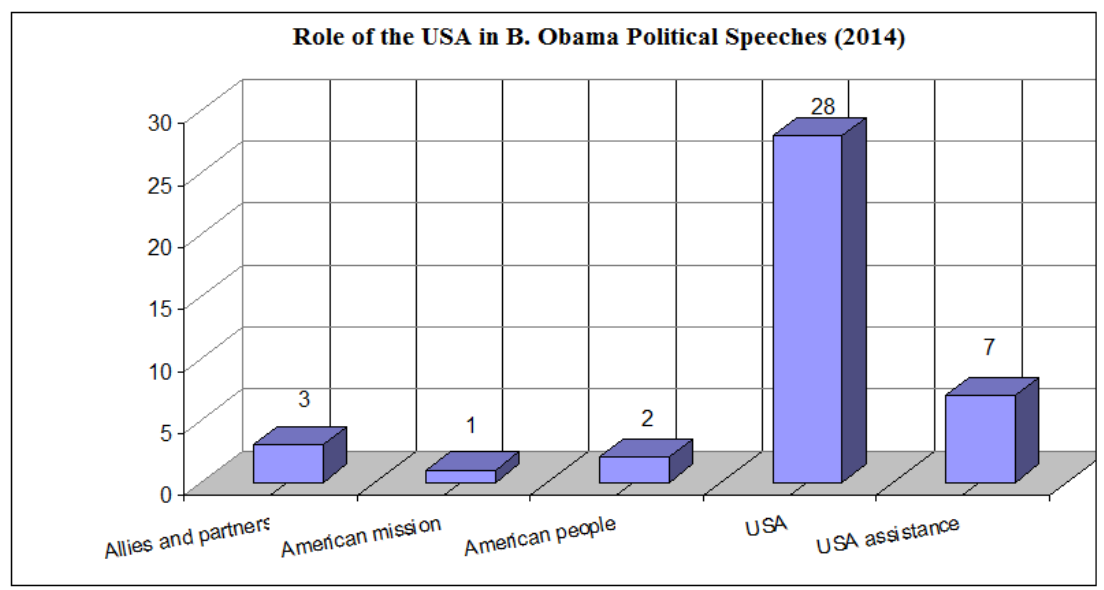

Figure 4: Role of the USA in the Russian-Ukrainian Conflict

The dominant indicator, and the most frequent, is the USA itself. The President, when discussing the issue of the conflict in Ukraine, mentions the United States as a pattern to follow. 
America, like Ukraine, struggle to freedom and independence through the waves of violence of the Wild West, the War of Independence between 1775 and 1783, the Civil War from 1861 to 1865, and other bloody events that served as a sacrifice for the formation of the United States of America as a modern, free, democratic and civilized country. In addition to this, America plays a tremendously important role as a mediator in the conflict; it has united its efforts with those of its European partners and NATO allies, and it has initiated the process of peace talks. The Secretary of State, John Kerry, has had regular meetings with the Russian Foreign Minister Sergei Lavrov.

In the current situation, the United States has taken decisive steps to unite efforts with its partners and allies. This is why Obama mentions the notions of allies and partners. Not less important is the economic and military assistance of the USA, which tries to stop the increase in Russian aggression. Obama, as well as the American political elite understands that in confrontation with the Russian Federation, Ukraine has a slim chance of success, which is why it requires support and assistance. American politicians are eager to support Ukraine on the way to freedom and independence. Obama's speeches and actions prove this. For example:

Vice President Biden just spoke with Prime Minister - the Prime Minister of Ukraine to assure him that in this difficult moment, the United States supports his government's efforts and stands for the sovereignty, territorial integrity, and democratic future of Ukraine (Obama, 2014a).

In this speech, Obama stresses that the American political elite is willing to support Ukraine verbally and economically.

The ideas expressed above are proved by the facts. The United States supported Ukraine from the first days of the "Revolution of Dignity", which led to the end of Yanukovich's corrupt and lawless rule. American senators were the first foreign politicians who went to Maidan to support and inspire Ukrainians. Compare:

One last point: There's been a lot of talk in Congress about these issues. Today, once again, I'm calling on Congress to follow up on these words with action, specifically to support the $I M F$ 's capacity to lend resources to Ukraine and to provide American assistance for the Ukrainian Government so that they can weather this storm (Obama, 2014b).

Thus, the concept of Ukraine is closely connected with the concept of the USA.

The third model in the concept is represented by a more numerous group of notions entitled Future of Ukraine (see Fig. 5).

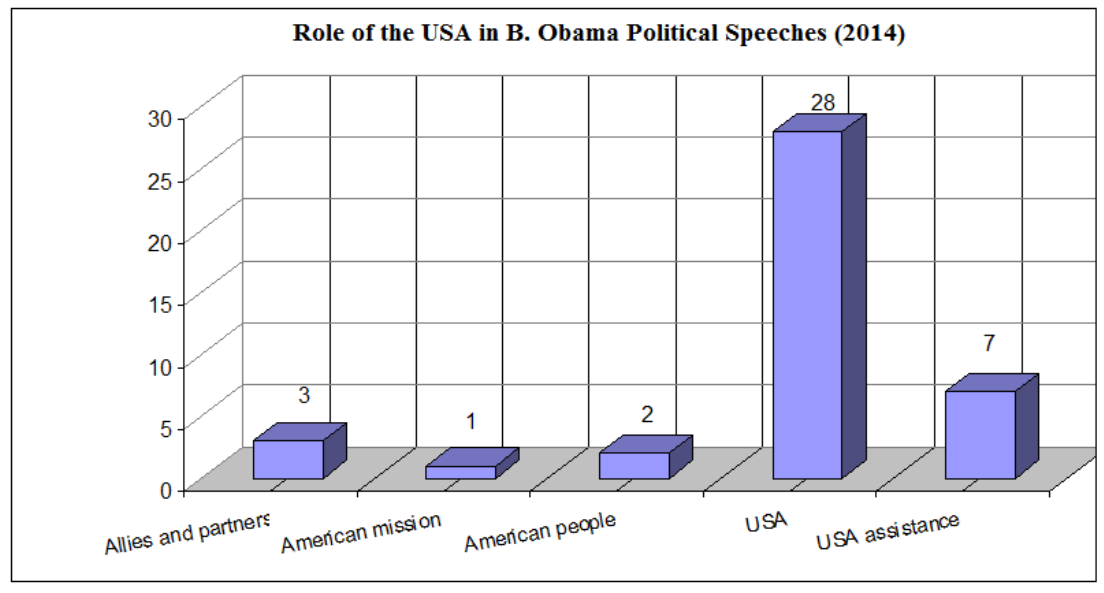

Figure 5: Future of Ukraine 
This model consists of 77 notions that are stylistically coloured, meaning that they have positive and negative connotations. Almost all of them are positive, as there is only one word with a pejorative connotation. It is the word corruption. The most numerous are democracy, Eastern Ukraine, elections in Ukraine, peace and order, people of Ukraine, prosperous Ukraine and reforms. Less numerous are corruption, economic growth, national dialogue, security, transparency etc. The latter notions are less numerous because they are less important in comparison with the democratic changes and the conflict situation. Ukraine is still at war with separatists supported by Russia both militarily and economically.

The key indicators of this group are the notions of President Poroshenko, Democracy, Eastern Ukraine, Elections in Ukraine, Peace and order, People of Ukraine, Prosperous Ukraine and Reforms. They reflect president Obama's perception of the situation in Ukraine through the prism of the liberal tradition. Obama is convinced that legitimate democratic process in Ukraine, such as parliamentary and presidential elections, guarantee the stability and development of the country in the economic, political and cultural spheres. The first steps on the road to freedom and independence are being taken by Ukrainians and President Poroshenko is a key element in this process. Obama also focuses on eastern Ukraine, which sparked the war between Moscow and Kiev. The high level of pro-Russian support and the position of the eastern region is a weak link in the whole chain, and it undermines the territorial integrity of the country.

Democracy is a basic notion in the rhetoric of American presidents. This lexeme reflects the understanding American political leaders have of the world, the basics of the state, and the direction of state development. Realizing that the USA is a God-blessed country, Obama is convinced that Ukraine, like many other countries in Europe and the world, should be based on democratic principles. As a politician loyal to these deeply-rooted traditions, he repeats the lexeme the USA, keeping in mind and articulating that America is a model country for the rest of the world.

The events of the past several months remind us of how difficult democracy can be in a country with deep divisions. But the Ukrainian people have also reminded us that human beings have a universal right to determine their own future (Obama, 2014a).

The indicator democracy is used frequently in Obama's speeches. The American leader, using the notion democracy, continues the liberal tradition of former presidents who accepted and supported the right of other nations to fight for freedom and to follow the democratic path of development. Analogies can be drawn with speeches delivered by J. Kennedy, R. Reagan, B. Clinton, G. Bush senior and G. Bush junior.

Democracy, for American presidents, is associated with freedom, which can only be achieved by confronting tyranny. The notion of democracy is quite numerous, which indicates that it occupies an important place in the mental and linguistic worldview of the American leader.

Along with democracy, another important indicator was identified in the speeches. It is President Poroshenko, who serves as a guarantor of the democratic processes and the country's economic, internal and external political reconstruction. Compare:

I'm going to continue to engage President Putin as well as President Poroshenko and our European partners in pursuit of such a diplomatic solution. But it is important for Russia to understand that, meanwhile, we will continue to support the people of Ukraine, who have elected a new President, who have deepened their ties with Europe and the United States, and that the path for a peaceful resolution to this crisis involves recognizing the sovereignty, the territorial integrity, and the independence of the Ukrainian people (Obama, 2014j).

The newly elected Ukrainian President P. Poroshenko, for Obama, is a symbol of democracy, freedom and the choice of the Ukrainian people. This is why he is referred to so often in the speeches of the American president.

The model of democracy in the mental worldview presupposes the availability of the indicators president, people of Ukraine, democratic elections etc. As soon as the war between Russia and Ukraine comes to an end, the less numerous notions will become more important in the political discourse of Obama. 


\section{Conclusions}

In modern political discourse, new concepts are important means of influence. The concept of Ukraine is the latest concept in the worldview of American politicians. It was created as a result of the aggressive actions of the Russian Federation. This concept not only reflects the status quo of the situation, but also the solutions to the problems faced by all the players in Eastern, Central, and Western Europe.

The analysis of the linguistic means identified in the speeches of Barak Obama prove how important political speeches are for the creation of the positive image of the USA in the light of events in eastern Ukraine.

After analyzing the political speeches and identifying their key elements, one can come to the conclusion that they reflect the linguistic and mental worldview of American leaders. The notions which have been selected and analyzed correlate with the idea that the United States serves as the basis of freedom, democracy and state formation and, at the same time, acts as a model of democracy and rule of law for other countries to follow.

The concept of Ukraine in the mind of the American elite is associated with a set of models represented by groups of notions such as conflict, the USA, peaceful solution, allies and partners, democracy, reforms, elections, President Poroshenko, Ukrainian people etc.

The analysed speeches prove that there are basic ideas which are important for American leaders in the light of the liberal tradition. They are democracy, peace, elections, president, and reforms. These notions reflect the American leaders' comprehension of the world, their perception of events, and solutions to problems. The actions that accompany and follow political speeches indicate that the USA is ready to stand by its leaders' words.

The next logical step for further study is analysis of the concepts of Russia and Europe, which highlight the nuances of the mental worldview of American political leaders.

\section{References}

Altunian, A. G. (2006). Analiz politicheskikh tekstov. Moskva: Universitetskaia kniga.

Andrusiak, I. V. (2008). Leksyka politychnoii korektnosti: Nominatyvnyi ta pragmatychnyi aspekty. In M. P. Fabian (Ed.), Suchasni doslidzhennia z inozemnoii filologii (Pt. 6, pp. 41-46). Uzhhorod: Papirus-F.

Bondarenko, Y. B. (2005). Kartyna svitu i diskurs: Realizatsiia dualnoii pryrody liudyny. In I. S. Shevchenko (Ed.), Dyskurs iak kognityvno-komunikatyvnyi fenomen (pp. 36-64). Kharkiv: Konstanta.

Butova, I. S. (2011). Pragmatyko-funktsionalni osoblyvosti politychnoho diskursy SSHA ta Ukraiiny XXI stolittia: Avtoref. dys. na zdobuttia nauk. stupenia k. filol. n.: spets. 10.02.17 "Porivnialno-istorychne i typologichne movoznavstvo". Lviv.

Chudinov, A. P. (2007). Politicheskaia lingvistika. Moskva: Nauka.

Deik, T. A. van (1989). Iazyk. Poznaniie. Komunikatsiia. Moskva: Progres s.

Fomenko, O. S. (1998). Lingvistychnhyi analiz suchasnoho politychnoho diskursy SSHA (90-ti roky XX stolittia) (Avtoref. dis. . kand. filol. nauk: 10.02.04). Kyiivskyi universytet imeni Tarasa Shevchenka, Kyiv.

Górska, E. (2010). LIFE IS MUSIC: A case study of a novel metaphor and its use in discourse. English Text Construction, 3(2) (Special Issue: Textual choices and discourse genres: Creating meaning through form, edited by B. Dancygier \& J. Sanders), 275-293.

Górska, E. (Ed.). (1993). Images from the cognitive scene. Kraków: Universitas.

Hart, R., Jarvis, S., Jennings, W., \& Smith-Howell, D. (2005). Political keywords: Using language that uses us. New York: Oxford University Press.

Joint Statement by Group of Seven Leaders on foreign policy. (2014, June 4). Retrieved January 20, 2015, from http://www.presidency.ucsb.edu/ws/index.php?pid=105237\&st.

Joint Statement by Group of Seven Leaders on the situation in Ukraine. (2014a, March 2). Retrieved from http://www.presidency.ucsb.edu/ws/index . php?pid=104789. 
Joint Statement by Group of Seven Leaders on the situation in Ukraine. (2014b, July 30). Retrieved from http://www . presidency.ucsb.edu/ws/index .php?pid=106613\&st.

Joseph, J. (2006). Language and politics. Edinburgh: Edinburgh University Press. http://dx.doi.org/ 10.3366/edinburgh/9780748624522.001.0001.

Kirkpatrick, M. (2009). Word cloud analysis of Obama's inaugural speech, compared to Bush, Clinton, Reagan, Lincoln's. Retrieved January 20, 2015, from http://readwrite.com/2009/01/20/tag_ clouds_of_obamas_inaugural_speech_compared_to_bushs.

Krzywinski, M. (2015). Lexical analysis of 2012 presidential debates — Obama vs Romney. Retrieved from http://mkweb.bcgsc.ca/debates2012/.

Lakoff, G. (1980). Metaphors we live by. Chicago: The University of Chicago Press.

Lakoff, G. (1996). Moral politics. Chicago: The University of Chicago Press.

Lakoff, G. \& Johnson, M. (1999). Philosophy in the flesh: The embodied mind and its challenge to Western thought. New York: Basic Books.

Levitskii, A. (1998). Funktsionalnyie podhody $k$ klasifikatsii yedinits sovremennoho angliiskoho yazyka. Kyiv: ASA.

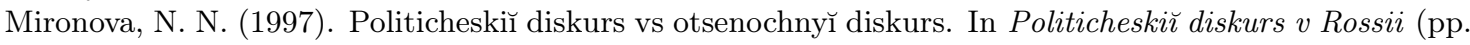
41-50). Moskva: Nauka.

Obama, B. (2014a, February 28). Remarks on the situation in Ukraine. Retrieved from http://www . presidency $\cdot$ ucsb. edu/ws/?pid=104756.

Obama, B. (2014b, March 6). Remarks on the situation in Ukraine. Retrieved from http://www. presidency .ucsb.edu/ws/index.php?pid=104852\&st.

Obama, B. (2014c, March 12). Remarks following a meeting with Prime Minister Arseniy Yatsenyuk of Ukraine and an exchange with reporters. Retrieved from http://www.presidency.ucsb.edu/ws/ index $\cdot$ php?pid=105028\&st=\&st 1 .

Obama, B. (2014d, March 17). Remarks on the situation in Ukraine. Retrieved from http://www. presidency .ucsb.edu/ws/index.php?pid=105040\&st.

Obama, B. (2014e, March 20). Remarks on the situation in Ukraine. Retrieved from http://www. presidency $\cdot$ ucsb.edu/ws/index .php?pid=105045\&st.

Obama, B. (2014f, April 17). The President's news conference. Retrieved from http://www.presidency . ucsb.edu/ws/index .php?pid=105118\&st.

Obama, B. (2014g, May 25). Statement on the presidential election in Ukraine. Retrieved from http: //www.presidency . ucsb.edu/ws/index . php?pid=105213\&st.

Obama, B. (2014h, May 28). Commencement address at the United States Military Academy in West Point, New York. Retrieved from http://www.presidency.ucsb.edu/ws/index.php?pid=105220\&st.

Obama, B. (2014i, June 4). Remarks following a meeting with President-Elect Petro Poroshenko of Ukraine in Warsaw, Poland. Retrieved from http://www.presidency.ucsb.edu/ws/index.php?pid= 105245\&st.

Obama, B. (2014j, July 29). Remarks on the situation in Ukraine. Retrieved from http://www .presidency . ucsb.edu/ws/index.php?pid=105500\&st.

Obama, B. (2014k, September 11). Statement on international sanctions against Russia. Retrieved from http://www.presidency.ucsb.edu/ws/index.php?pid=107488\&st.

Obama, B. (2014l, October 27). Statement on parliamentary elections in Ukraine. Retrieved from http: //www . presidency . ucsb.edu/ws/index . php?pid=107822\&st.

Pavilionis, R. I. (1983). Problema smysla: Sovremennyı logiko-filosofskiu analiz iazyka. Moskva: Mysl'.

Pocheptsov, G. G. (junior). (1999). Informatsionnyie vorny: Osnovy voenno-kommunikativnykh issledovaniu. Rovno: PPF Volynski oberegy.

Pocheptsov, G. G. (junior ). (2000). Imidzhelogiia. Moskva: Refl-buk.

Serazhym, K. (2002). Diskurs iak sotsiolingvalne iavyshche: Metodologiia, arhitektonika, variatyvnist. Kyiv: KNU.

Sheigal, Y. I. (2002). Inavguratsionnoe obrashcheniie kak zhanr politicheskoho diskursa (pp. 205-214). In Zhanry rechi (Vol. 3). Saratov.

Shveitser, A. D. (1976). Sovremennaia sotsiolingvistika: Teorii, problemy, metody. Moskva: Nauka.

Tabakowska, E. (2004a). Kognitywizm po polsku - wczoraj i dziś. Kraków: Universitas.

Tabakowska, E. (2004b). Językoznawstwo kognitywne a poetyka przekładu. Kraków: Universitas.

Wierzbicka, A. (1992). Semantics, culture and cognition. Universal human concepts in culture. Specific configurations. Oxford: Oxford University Press. 


\section{Acknowledgment}

This work was supported by a core funding for statutory activities from the Ministry of Education and Science of Ukraine.

The author declares that he has no competing interests.

This is an Open Access article distributed under the terms of the Creative Commons Attribution 3.0 PL License (http://creativecommons.org/licenses/by/3.0/pl/), which permits redistribution, commercial and noncommercial, provided that the article is properly cited.

(C) The Author 2016

Publisher: Institute of Slavic Studies, Polish Academy of Sciences, University of Silesia \& The Slavic Foundation 